\title{
Reductive dissolution of scorodite in the presence of Shewanella sp. CN32 and Shewanella sp. ANA-3
}

\author{
Erika Revesz ${ }^{\mathrm{a}}$, Danielle Fortin ${ }^{\mathrm{a}^{*}}$, Dogan Paktunc ${ }^{\mathrm{a}, \mathrm{b},{ }^{*}}$
}

a University of Ottawa, Department of Earth and Environmental Sciences, 25 Templeton St, Ottawa, Ontario, Canada, K1N 6N5.

${ }^{\mathrm{b}}$ CANMET Mining and Mineral Sciences Laboratories, 555 Booth Street, Ottawa, Ontario, Canada, K1A 0G1

*Corresponding authors: dfortin@uottawa.ca

Dogan.Paktunc@NRCan-RNCan.gc.ca 


\section{Abstract}

Mining and mineral processing operations may generate a wide range of As-rich compounds including scorodite $\left(\mathrm{FeAsO}_{4} \cdot 2 \mathrm{H}_{2} \mathrm{O}\right)$, a common secondary arsenate in near-surface environments and some gold mine tailings. Scorodite has a low solubility in a limited $\mathrm{pH}$ range, and it is relatively stable under near-surface conditions, but its behavior under the influence of bacteria is not well understood. Considering that reducing conditions are likely to develop in mine tailings with depth and under prolonged disposal conditions, the present study was undertaken to determine the influence of bacteria on the reductive dissolution of scorodite. Because the systematic studies on the microbial reduction of scorodite are lacking, we used two well characterized dissimilatory iron and arsenic reducing bacteria, i.e., Shewanella sp. ANA-3 and Shewanella putrefaciens CN32in a chemically defined media, at circumneutral $\mathrm{pH}$, containing various phosphate concentrations (i.e., 15, 40 and $400 \mu \mathrm{M}$ ). The initial rates of reduction and the plateau concentrations of reduced species formed in the aqueous phase were greater in the presence of Shewanella sp. ANA-3 than in the presence of Shewanella putrefaciens CN32. The initial rate of reduction was found to increase with increasing phosphate concentration, however, plateau concentrations of the dissolved reduced species, $\mathrm{Fe}(\mathrm{II})$ and $\mathrm{As}(\mathrm{III})$, formed in the aqueous phase were highest at the lowest phosphate concentration. The solid products of the post-reduction samples were characterized by synchrotron X-ray absorption spectroscopy (XAS) and powder X-ray diffraction $(\mathrm{XRD})$, scanning, transmission and high resolution electron microscopy (SEM/TEM/HRTEM) and energy dispersive spectrometry (EDS). The results indicate 
that the post reduction solids contained scorodite, a biogenic ferrous arsenite and parasymplesite $\left(\mathrm{Fe}_{3}\left(\mathrm{AsO}_{4}\right)_{2} \cdot 8 \mathrm{H}_{2} \mathrm{O}\right)$. Phosphate concentrations had an effect on the concentrations of released $\mathrm{Fe}(\mathrm{II})$ and $\mathrm{As}$ (III) during the microbial reduction and the formation of secondary phases. The influence of bacteria on the reductive dissolution of scorodite must be taken into consideration during mine waste management and disposal operations because of the potential of arsenic releases to terrestrial and aquatic environments as toxic and soluble As(III) species.

\section{Introduction}

Anthropogenic activities, such as mining of gold and base metal ores, and related metallurgical processing including gold roasters and base metal smelters can result in the generation of significant arsenic concentrations in the waste products (Vaughan, 2004; Paktunc, 2008a, 2009). For instance, roasting operations at the Giant Mine alone (Northwest Territories, Canada) produced 237,000 tons of arsenic trioxide dust, currently stored in sealed underground chambers at the mine site. Mine tailings produced from the gold mining and processing operations at the Ketza River Mine (Yukon, Canada) contain significant As concentrations reaching up to $\sim$ wt \% (Paktunc et al. 2003), which amounts to $~ 17,000$ tons of arsenic in the tailings.

Arsenopyrite (FeAsS), pyrite $\left(\mathrm{FeS}_{2}\right)$ which can contain significant concentrations of As (Paktunc 2008a) and their oxidation products formed during pressure-leaching, roasting and bacterial oxidation to liberate the gold in refractory gold ores constitute the primary sources of arsenic in mining and metallurgical wastes (Paktunc, 2008b; Paktunc 
et al. 2013). Under atmospheric conditions, arsenic can be released to the environment as a result of the oxidative dissolution of pyrite and arsenopyrite.

Scorodite $\left(\mathrm{FeAsO}_{4} \cdot 2 \mathrm{H}_{2} \mathrm{O}\right)$, a widespread ferric arsenate mineral in near surface environments, can form as a result of As-pyrite and arsenopyrite oxidation and as a precipitate from mine drainage and effluents (Paktunc et al. 2004; 2008a, Walker et al. 2009; Corriveau et al., 2011). Scorodite which can form from ferric arsenate solutions at atmospheric conditions has the potential to stabilize arsenic in mine effluents (Paktunc et al. 2008). Consequently, the stability and solubility of scorodite has been the subject of many investigations. Scorodite has a relatively low solubility, $\mathrm{Ksp}=10^{-24}$ to $10^{-26}$ (Langmuir et al. 2006; Paktunc and Bruggeman, 2010; Majzlan et al. 2012). Scorodite dissolves incongruently above $\mathrm{pH} \sim 3$ (Krause and Ettel, 1989; Harvey et al. 2006) leading to the formation of ferrihydrite and the release of arsenic (Langmuir, et al. 2006 and references therein; Paktunc and Bruggeman, 2010; Majzlan et al. 2012) and transforms to calcian ferric arsenates in Ca-rich solutions at slightly acidic to neutral conditions (Paktunc et al. 2015). Scorodite can undergo microbial reductive dissolution with dissimilatory iron reducing bacteria (DIRB) (Cummings et al. 1999; Papassiopi et al., 2003) resulting in the release of $A s(V)$ or with dissimilatory arsenic reducing bacteria (DARB) resulting in As(III) releases (Newman et al., 1997). At the Zloty Stok gold mining site in Poland, Drewniak et al., $(2009,2010)$ found that a variety of microorganisms, including dissimilatory arsenic reducing bacteria (DARB) reduce $A s(V)$ in scorodite to $\mathrm{As}(\mathrm{III})$ and release it to the groundwater. As(III) is more mobile and bioavailable than $\mathrm{As}(\mathrm{V})$, and it has a much higher affinity for sulfhydryl (-SH) groups of proteins than $\mathrm{As}(\mathrm{V})$. The $-\mathrm{SH}$ groups are part of the catalytic sites of many enzymes, 
and $\mathrm{As}(\mathrm{III})$ blocks these sites more readily than $\mathrm{As}(\mathrm{V})$ and inactivating up to 200 enzymes (Shen et al. 2013).

Systematic studies on the microbial reduction of scorodite are lacking, especially studies involving bacteria, which can function both as dissimilatory iron and arsenic reducers. Arsenic respiring microorganisms are fairly common in nature, and belong to several genera in the domain of Bacteria and also Archaea (Macur et al., 2004; Oremland and Stolz, 2005; Stolz et al. 2006). A phylogenetic tree based on 16S rRNA sequences of bacteria and archaea that are capable of transforming arsenic in a variety of habitats and range of environmental conditions was recently published by Cavalca et al. (2013). The dissimilatory arsenic reducing bacteria (DARB) are metabolically diverse and they are capable of using different organic compounds as electron donors including lactate, acetate, butyrate, pyruvate and malate (Newman et al., 1998), and as electron acceptors, such as $\mathrm{Fe}^{3+}$ in iron oxides, sulphate and nitrate (Lovely, 2001). The genus Psychrobacter was recently reported to have $\mathrm{As}(\mathrm{V})$ reducing ability (Liao et al., 2011), whereas Sulfurospirillum barnesii has been found to be able to respire a broad spectrum of potential electron acceptors including As(V) and Fe(III) (Zobrist et al. 2000).

Phosphate, especially at high concentrations, can enhance the desorption of $\mathrm{As}(\mathrm{V})$ because of competition for adsorption sites (Smedley, D.G. Kinniburgh, 2002). Phosphate can also influence bacterial activity by adsorbing on the solid surface of Asand Fe-rich minerals which alters the surface reactivity (Borch et al. (2007), and can influence the formation of post-reduction secondary mineral phases. Although Newman et al., (1997) used $1 \mathrm{mM}$ phosphate, and Papassiopi et al., (2003) used $0.72 \mathrm{mM}$ phosphate in the growth medium, which are within the range of typical $0.1-1.5 \mathrm{mM}$ 
phosphate concentrations in tailings pore waters (Langmuir et al. 1999; Praharaj and Fortin, 2008), the bacteria they used only reduced either $\mathrm{As}(\mathrm{V})$ or $\mathrm{Fe}(\mathrm{III})$. Microbial reduction studies involving ferrihydrite have been performed at different phosphate concentrations (Frederickson et al., 1998; Kukkadapu et al. 2004; Borch et al. 2007; Amstaetter et al., 2012). Phosphate concentration was found to have a significant effect on the extent of reduction and biotransformation of ferrihydrite with the formation of vivianite $\left(\mathrm{Fe}_{3}\left(\mathrm{PO}_{4}\right)_{2} \cdot 8 \mathrm{H}_{2} \mathrm{O}\right)$ at $20 \mathrm{mM}$ phosphate concentration (Kukkadapu et al. The microbial reduction of ferrihydrite at $4 \mathrm{mM}$ phosphate concentrations resulted in the formation of secondary phases of siderite and vivianite (Fredrickson et al. 1998), and magnetite, vivianite and green rust (Borch et al. 2007). Amstaetter et al. (2012) reported that phosphate decreased the reduction rates by adsorption onto ferrihydrite and blocked the surface sites. Comparable microbial reduction studies using different phosphate concentrations do not exist for scorodite.

In this paper, we investigate scorodite reducing abilities of two different bacterial strains, Shewanella putrefaciens CN32 and Shewanella sp. ANA-3 at three different phosphate concentrations $(15,45,400 \mu \mathrm{M})$ representative of natural environments, and provide the characterization of the secondary solid phases by X-ray diffraction, X-ray absorption spectroscopy and scanning and transmission electron microscopy techniques. The goal of the present study is to determine the influence of bacteria on the stability of scorodite and assess the potential fate of arsenic in mine wastes.

\section{Materials and methods}

\subsection{Scorodite synthesis}


Scorodite samples were synthesized at Canada Centre for Mineral and Energy Technology (CANMET) (Ottawa, Canada), using $0.2 \mathrm{M} \mathrm{Fe}\left(\mathrm{SO}_{4}\right)_{1.5}$ and $0.2 \mathrm{M} \mathrm{Na}_{2} \mathrm{HAsO}_{4}$ solutions heated at $70{ }^{\circ} \mathrm{C}$ and adjusted to $\mathrm{pH} 2$ in batch reactors as described by Paktunc et al., (2008). The samples were characterized by X-ray diffraction (XRD) using a Rigaku rotating anode $\mathrm{X}$-ray powder diffractometer with a $\mathrm{Cu} \mathrm{K} \alpha$ radiation at $55 \mathrm{kV}$, $180 \mathrm{~mA}$, a step-scan of $0.04^{\circ}$ and a scan rate of 1 and $2^{\circ} / \mathrm{min}$ in $2 \theta$. The samples were pure and did not contain the precursor ferric arsenate. Gamma-radiation was used to sterilize the samples prior to their use in the microcosms. The total exposure was 48 kGray. According to Langley et al. (2009), gamma radiation causes little physical and mineralogical changes.

\subsection{Maintenance and growth of the bacterial strains}

Shewanella sp. strain ANA-3 was provided by Dr. Chad Saltikov (University of California, Santa Cruz). Shewanella putrefaciens CN32 and Shewanella sp. ANA-3 were maintained on tryptic soy agar $(\mathrm{TSA})$ at room temperature $\left(\sim 23^{\circ} \mathrm{C}\right)$. A chemically defined growth medium (CDM) was used for the anaerobic growth of both strains during the microcosm experiments. The medium contained $20 \mathrm{mM}$ sodium lactate, $4.5 \mathrm{mM}$ 1,4piperazine-diethanesulfonic acid (PIPES) buffer, $0.01 \mathrm{mM}$ nitriloacetic acid and trace element salts, including $0.1 \mathrm{mM} \mathrm{MgSO}_{4} \cdot 7 \mathrm{H}_{2} \mathrm{O}, 2.6 \mu \mathrm{M} \mathrm{MnSO}{ }_{4} \cdot \mathrm{H}_{2} \mathrm{O}, 0.15 \mathrm{mM} \mathrm{NaCl}$, $3.2 \mu \mathrm{M} \mathrm{FeSO}{ }_{4} \cdot 7 \mathrm{H}_{2} \mathrm{O}, 3.8 \mu \mathrm{M} \mathrm{CoCl}{ }_{2} \cdot 6 \mathrm{H}_{2} \mathrm{O}, 6.1 \mu \mathrm{M} \mathrm{CaCl}_{2} \cdot 2 \mathrm{H}_{2} \mathrm{O}, 0.93 \mu \mathrm{M} \mathrm{NaMoO}_{4}$. $2 \mathrm{H}_{2} \mathrm{O}, 0.36 \mu \mathrm{M} \mathrm{CuSO} \mathrm{C}_{4} \cdot 5 \mathrm{H}_{2} \mathrm{O}, 0.19 \mu \mathrm{M} \mathrm{AlK}\left(\mathrm{SO}_{4}\right)_{2} \cdot 12 \mathrm{H}_{2} \mathrm{O}, 1.5 \mu \mathrm{M} \mathrm{H}_{3} \mathrm{BO}_{3}, 0.68 \mu \mathrm{M}$ $\mathrm{Na}_{2} \mathrm{WO}_{4} \cdot 2 \mathrm{H}_{2} \mathrm{O}, 0.91 \mu \mathrm{M} \mathrm{NiCl} \cdot 6 \mathrm{H}_{2} \mathrm{O}$ (Langley et al., 2009). In order to test the effect of phosphate concentration on the reduction rates, the concentration of $\mathrm{PO}_{4}{ }^{3-}$ 
$\left(\mathrm{Na}_{2} \mathrm{HPO}_{4}\right)$ was progressively lowered from $\sim 4 \mathrm{mM}$ to $400 \mu \mathrm{M}, 45 \mu \mathrm{M}$ and $15 \mu \mathrm{M}$, which is far less than the usually recommended phosphate concentration of $3.9 \mathrm{mM}$ (Glasauer et al., 2003).

Prior to the reduction experiment, a single colony of each strain was transferred aseptically from the TSA plates to $50 \mathrm{~mL}$ of autoclaved tryptic soy broth (TSB) at $23^{\circ} \mathrm{C}$ and grown aerobically on a rotary shaker set at $160 \mathrm{rpm}$. After 24 hours, $0.5 \mathrm{~mL}$ of each culture was transferred into $50 \mathrm{~mL}$ of 50:50 TSB:CDM mixtures containing $30 \mu \mathrm{M}$ phosphate. After another 24 hours, the sub-culturing procedure was repeated with 5:95 TSB:CDM mixtures containing $50 \mu \mathrm{M}$ phosphate in order to adapt the cells to the nutrient conditions of the CDM. The final step involved growing the bacteria in $100 \%$ $\mathrm{CDM}$ and $100 \mu \mathrm{M}$ phosphate concentration for $36 \mathrm{~h}$ at $23^{\circ} \mathrm{C}$, prior to their use in the microcosms (containing either $400 \mu \mathrm{M}, 45 \mu \mathrm{M}$ or $15 \mu \mathrm{M}$ of phosphate). Each final culture contained $0.5 \mu \mathrm{g} / \mathrm{mL}$ of total protein, based on the protocol used by Glasauer et al. (2003), which corresponded roughly to $10^{8}$ cells $/ \mathrm{mL}$.

\subsection{Microcosms setup and sampling}

The biotic systems consisted of $150 \mathrm{~mL}$ of sterile CDM (containing $15 \mu \mathrm{M}, 45 \mu \mathrm{M}$ or $400 \mu \mathrm{M} \mathrm{PO}_{4}{ }^{3-}$ ) in $500 \mathrm{~mL}$ acid-washed, sterilized Kimax bottles. Synthetic scorodite $(0.40 \pm 0.02 \mathrm{~g})$ was added to each bottle, which amounted to $11.5 \mathrm{mM}$ of $\mathrm{Fe}(\mathrm{III})$ and $\mathrm{As}(\mathrm{V})$ in the form of $\mathrm{FeAsO}_{4} \cdot 2 \mathrm{H}_{2} \mathrm{O}$. The $\mathrm{pH}$ was adjusted to $7.00 \pm 0.03$ by the addition of 3 drops of $6 \mathrm{M} \mathrm{NaOH}$ prior to placing the microcosm bottles into the anaerobic chamber. The Kimax bottles were wrapped with aluminum foil in order to avoid possible photochemical effects. The microcosm bottles were inoculated inside an anaerobic 
chamber. Abiotic control samples were identical to the biotic ones, but did not contain Shewanella putrefaciens CN32 or Shewanella sp. strain ANA-3. Sampling was performed at room temperature inside the anaerobic chamber (atmosphere of $5 \%$ $\mathrm{H}_{2}: 95 \% \mathrm{~N}_{2}$ ). The experiments were conducted in duplicates for ANA-3, CN32 and controls. Sub-sampling of each system was performed right after the systems were inoculated (time 0 ) and then periodically at 24-hour intervals over a period of 7 days. For each sub-sampling, the bottles were first shaken vigorously and $10 \mathrm{~mL}$ aliquots were immediately removed into sterile $10 \mathrm{~mL}$ centrifuge tubes while the solid phase material remained suspended in the bottle. An aliquot of $7 \mathrm{~mL}$ of sample was passed through a $0.22 \mu \mathrm{m}$ nylon syringe filter into another $10 \mathrm{~mL}$ centrifuge tube for the determination of dissolved Fe. The rest of the aliquots were used for total Fe, culturing, Eh and $\mathrm{pH}$ measurements. To prevent possible bacterial cross contamination during sampling, only one microcosm bottle was open at a time and after sampling, the bottle cap was rinsed with $70 \%$ ethanol.

\subsection{Cell counts}

The Most Probable Number (MPN) method was used for cell counting and was performed as follows. A $0.5 \mathrm{~mL}$ sub-sample was aseptically removed from each bottle. From this sub-sample, $0.1 \mathrm{~mL}$ was used to prepare a 10 fold dilution series (five times) for cell count as described by Langley et al. (2009). The cells were placed onto sterile TSA plates and incubated at $23{ }^{\circ} \mathrm{C}$ for 24 to 48 hours prior to counting the colonies for both strains. 


\subsection{Chemical analyses}

Redox potential measurements were performed inside the anaerobic chamber using a Corning redox Platinum and $\mathrm{Ag} / \mathrm{AgCl}$ combination electrode (Corning Inc.). The same sub-sample was then removed from the anaerobic chamber for the measurement of $\mathrm{pH}$ using a standard laboratory $\mathrm{pH}$ meter and probe (VWR). Dissolved iron and arsenic concentrations were determined immediately after sampling using colorimetric methods. For dissolved concentrations, a $0.5 \mathrm{~mL}$ aliquot of the filtrate was transferred into $4.5 \mathrm{~mL}$ of $0.5 \mathrm{M} \mathrm{HCl}$, and used for the determination of $\mathrm{Fe}(\mathrm{II})$, arsenate, arsenite and phosphate. The ferrozine method (Stookey, 1970) modified to allow for the analysis of small sample volumes (Pepper et al., 2010), was used for the determination of $\mathrm{Fe}(\mathrm{II})$ and $\mathrm{Fe}(\mathrm{III})$ concentrations. The dissolved $\mathrm{Fe}(\mathrm{II})$ concentration was determined by adding $100 \mu \mathrm{L}$ of acidified filtrate to $900 \mu \mathrm{L}$ of $4.06 \times 10^{-4} \mathrm{M}$ ferrozine $\left(0.2 \mathrm{~g} \mathrm{~L}^{-1}\right.$ in 0.25 M HEPES, N-2-hydroxyethylpiperazine-N'-2-ethanesulfonic acid buffer, Sigma-Aldrich). The absorbance of this solution was measured within 15 minutes at $562 \mathrm{~nm}$ using an Ultrospec 1100 Pro UV/VIS spectrophotometer (GE Healthcare). A $500 \mu \mathrm{L}$ aliquot of unfiltered suspension was mixed with $500 \mu \mathrm{L}$ of $12 \mathrm{M}$ trace metal grade $\mathrm{HCl}$, to dissolve the solids, and this solution was used for the determination of bulk $\mathrm{Fe}(\mathrm{II})$ in solution and suspended solids combined. A $1.00 \mathrm{~mL}$ aliquot of this solution was diluted to $5.00 \mathrm{~mL}$ of Millipore deionized water, and $100 \mu \mathrm{L}$ of this diluted solution was mixed with $900 \mu \mathrm{L}$ of reducing agent, $0.28 \mathrm{M}$ hydroxylamine hydrochloride in a $0.28 \mathrm{M} \mathrm{HCl}$ solution. After allowing 40 minutes for the reduction of $\mathrm{Fe}(\mathrm{III}), 100 \mu \mathrm{L}$ of this solution was added to 900 $\mu \mathrm{L}$ of the ferrozine solution, and the absorbance was measured after 20 minutes. The dissolved $\mathrm{Fe}(\mathrm{III})$ concentration in the filtered sample was determined as the difference 
between the $\mathrm{Fe}(\mathrm{II})$ concentration after hydroxylamine reduction and the $\mathrm{Fe}(\mathrm{II})$ concentration prior to reduction (Viollier et.al. 2000; Pepper et. al. 2010).

Dissolved As(III) (arsenite), As(V) (arsenate) and phosphate concentrations were determined with the spectrophotometric molybdenum blue method developed by Johnson and Pilson (1972) and modified by Dhar (2004). Arsenate and phosphate form a blue colored complex with reduced molybdate which absorbs at $880 \mathrm{~nm}$, while arsenite does not. Three portions of a given sample were used to determine the concentration of these three species. One portion was treated with a reducing agent, sodium metabisulfite $\mathrm{Na}_{2} \mathrm{~S}_{2} \mathrm{O}_{5}$ with sodium thiosulfate $\mathrm{Na}_{2} \mathrm{~S}_{2} \mathrm{O}_{3} \cdot 5 \mathrm{H}_{2} \mathrm{O}$, which reduces arsenate to arsenite. This reduced portion mixed with the molybdate color agent had an absorbance $A_{\text {Red }}$, related to phosphate concentration. A second portion mixed with a color agent gave an absorbance $A_{U n t r}$, which was the sum of the absorbances due to arsenate and phosphate. $A_{U n t r}-A_{\text {Red }}$, the difference between the absorbance for the untreated sample (Untr) and the reduced sample (Red), provided the absorbance due to arsenate. A third portion of the sample was treated with an oxidizing agent $\mathrm{KIO}_{3}$, which oxidizes arsenite to arsenate. Aox, the absorbance for the oxidized sample mixed with the color agent was the sum of the absorbance values of phosphate and total arsenic. Therefore, $A_{O x}-A_{U n t r}$ equals the absorbance of arsenic proportional to the arsenite, As(III) concentration.

Standard mixtures of known concentrations of arsenite, arsenate and phosphate were used to validate the molybdenum blue method. As a further check on this method, total arsenic, total phosphorus, arsenite and arsenic where determined by inductively coupled plasma - optical emission spectroscopy (ICP-OES) using a Varian Vista-PRO 
CCD. The arsenite was isolated as the eluent obtained by passing a sample of filtrate through a solid phase extraction cartridge (Waters, Sep-Pak Plus) which retains the anionic species arsenate and phosphate, but does not retain $\mathrm{As}(\mathrm{OH})_{3}$ at the $\mathrm{pH}$ condition used for separation.

\subsection{Solid phase characterization}

$\mathrm{XRD}$ analyses of the bacterial post-reduction samples were carried out after washing and centrifuging the solids five times, and drying in the anaerobic chamber. A small amount of the powdered sample was placed in a 0.5 or $0.7 \mathrm{~mm}$ diameter glass capillary tube and sealed with carnauba wax in the anaerobic chamber. The samples

were kept in sealed containers, mounted on zero background plates and analyzed at CANMET with a Rigaku rotating anode $\mathrm{X}$-ray powder diffractometer with $\mathrm{Cu} \mathrm{K}_{\alpha}$ radiation at $50 \mathrm{kV}, 260 \mathrm{~mA}$, a step-scan of $0.04^{\circ}$ and a scan rate of 1 and $2^{\circ} / \mathrm{min}$ in $2 \theta$.

\subsection{Electron microscopy examinations}

For field emission scanning electron microscopy (FE-SEM) examinations, the samples were prepared by suspending a few $\mathrm{mg}$ of the solid sample in $99 \%$ ethanol, sonicating for 5 minutes and then placing one drop of the suspension onto a 300 mesh copper grid. After 10 minutes of drying, the sample was placed in the sample holder of the JEOL JSM-7500F Field Emission SEM equipped with an Oxford Instruments Silicon detector (University of Ottawa's Centre for Catalysis Research and Innovation - CCRI). The samples were examined at $1 \mathrm{kV}$ accelerating voltage in a lower secondary electron imaging mode. 
For environmental SEM analysis, a thin layer of the dry powdered sample was placed on a sticky carbon tape and analyzed using a JEOL JSM-6510LV SEM in low vacuum mode at $30 \mathrm{~Pa}$ in the Department of Earth Sciences at the University of Ottawa. For energy dispersive X-ray spectrometry (EDS) analysis, the X-Max Large Area Silicon Drift Detector (SDD) with a $20 \mathrm{~mm}^{2}$ active area was used. The applied accelerating voltage was $20 \mathrm{kV}$. The instrument was calibrated with a $\mathrm{Cu}$ tape, and the EDS spectrum was collected in the Analyzer Mode of the INCA Energy 350 spectrum analyzer software.

For transmission (TEM) and high resolution transmission electron microscopy (HRTEM) examination, the method of sample preparation was the same as for the FESEM. The Cu grid with the sample was placed into a JEOL JEM-2100F Field Emission Electron Microscope equipped with Oxford Instruments Silicon detector at the CCRI, University of Ottawa. The applied voltage was $200 \mathrm{kV}$ and the current density 0.6 $\mathrm{nA} / \mathrm{cm}^{2}$.

\subsection{X-ray absorption spectroscopy}

X-ray Absorption Spectroscopy (XAS) measurements were carried out at the undulator and at the bending magnet beamlines of the PNC-CAT facility at the Advanced Photon Source, Argonne National Laboratory. The undulator beamline, 20ID, was equipped with a $\mathrm{Si}(111)$ monochromator with $10^{-4} \mathrm{eV}$ resolution and a VortexME4 $^{\mathrm{TM}}$ Silicon Drift Detector. The samples were prepared as thin layers of powder distributed evenly on $\sim 3 \times 2 \mathrm{~cm}$ Kapton tape. The beam size was $4 \mu \mathrm{m}$, and nine $12 \mathrm{~dB}$ low pass, low noise filters were used to prevent beam damage. The fluorescence 
measurements included two-dimensional mapping of the As fluorescence intensity by using two slightly different As K-edge excitation energies. One was optimized to excite As(III) and the other to excite $A s(V)$. The two data sets were then superimposed in order to investigate the 2-D spatial distribution of $A s(I I I)$ and $A s(V)$ in the sample. Following fluorescence mapping, XANES spectra were collected from selected regions.

The setup at the bending magnet beamline (20-BM) included a $\mathrm{Si}(111)$ monochromator, a cryostat, ionization chambers and a 13 element Ge detector. Samples were prepared in the anaerobic chamber by mixing the powdered sample with boron nitride to dilute the arsenic concentration to about $1 \mathrm{wt} \%$. The samples were mounted in $15 \times 4 \mathrm{~mm}$ slots in Al sample holders, sealed with Kapton tape, and shipped to the APS in sealed anaerobic containers. The samples were placed in the cryostat at an angle of $45^{\circ}$ to the incident beam and to the Ge detector. The measurements were made at $-91 \pm 0.5 \mathrm{~K}$, using a beam size of $3500 \times 800 \mu \mathrm{m}$. Gold foil was used as a reference to monitor the shift in the K-edge energy. Data analysis was performed with ATHENA (Ravel and Newville, 2005).

\section{Results}

\subsection{Reduction experiments}

Redox conditions and cell counts

There was an initial small drop in $\mathrm{pH}$ after the bacteria were added to the microcosms, but the $\mathrm{pH}$ returned to the initial value of $7.00+/-0.03$ at the end of the reduction experiments in all systems (Table S.1, Supplementary information). The $\mathrm{pH}$ decreased from $\mathrm{pH} 7.00+/-0.03$ to $\mathrm{pH} 6.83$ in the abiotic control systems at all different 
phosphate concentrations. The initial redox values (Eh) were in the range of $350 \mathrm{mV}$ to $400 \mathrm{mV}$ for all systems at all phosphate concentrations (Fig. 1). During the first 72 hours, Eh values decreased significantly in both biotic systems reaching values of $0 \mathrm{mV}$ to $-100 \mathrm{mV}$, whereas over the same time interval, Eh values of the abiotic controls decreased from 280 to $230 \mathrm{mV}$ (Fig. 1). The Eh measurements were only qualitative because there were many redox couples in the system.

No viable bacterial cells were detected in the abiotic controls over the entire duration of the experiment. Initial cell counts in the biotic systems, were in the order of (1.2 to 1.4$) \times 10^{8} \mathrm{CFU} / \mathrm{mL}$ for $\mathrm{CN} 32$ and $(1.0$ to 1.2$) \times 10^{8} \mathrm{CFU} / \mathrm{mL}$ for ANA-3, which declined steadily over the course of the experiment to reach final values in the orders of $7.9 \times 10^{4}$ to $3.2 \times 10^{5} \mathrm{CFU} / \mathrm{mL}$ for $S$. CN32 and $2.5 \times 10^{5}$ to $3.2 \times 10^{5}$ for S. ANA-3, respectively (Fig. 1 and Table S.2, Supplementary information).

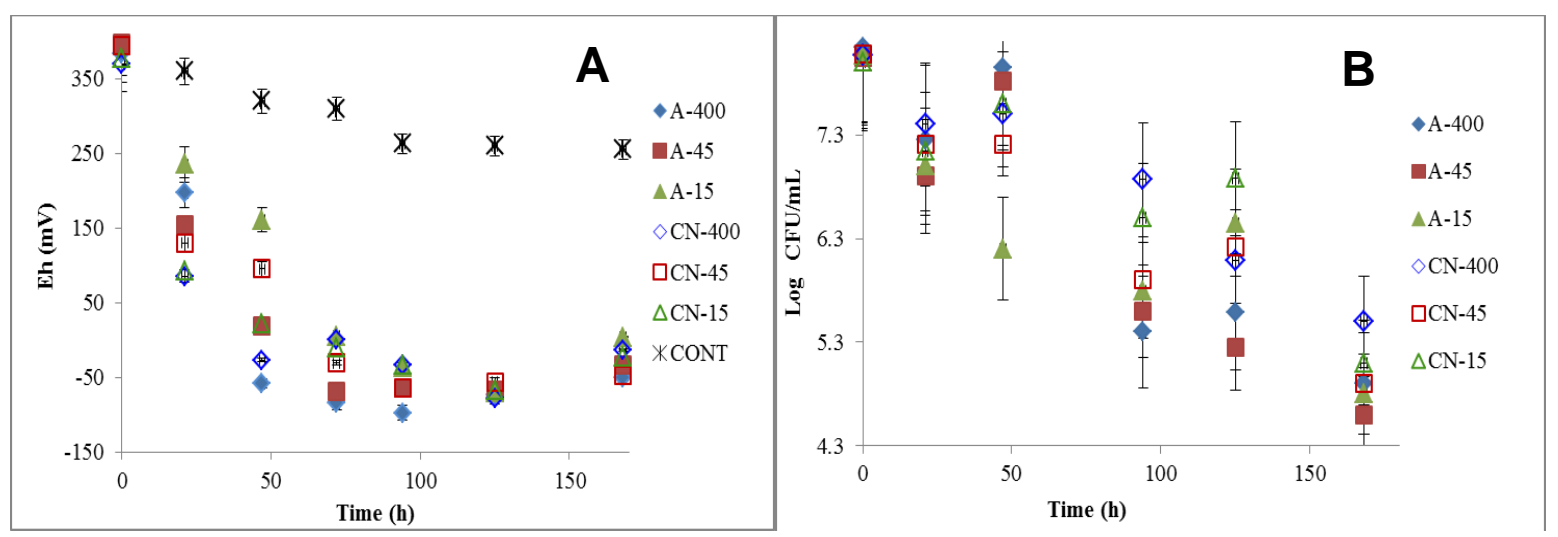

Figure 1. Redox conditions (A) and bacterial cell counts (B) during the reduction of scorodite in the control (CONT) and two biotic systems (in the legend, A stands for ANA and $\mathrm{CN}$ for CN32) in the presence of 400,45 and $15 \mu \mathrm{M}$ of phosphate.

Fe and As speciation during microbial reduction 
Both $\mathrm{Fe}$ and $\mathrm{As}$ were reduced and released into solution in all biotic systems (Figs 2 and 3), whereas only negligible amounts of dissolved Fe (II) and As (III) were present in the abiotic control experiments. The plateau concentrations of dissolved $\mathrm{Fe}(\mathrm{II})$ and $\mathrm{As}(\mathrm{III})$ in all biotic systems at all phosphate concentrations were always greater in the systems containing the ANA-3 strain than those containing CN32. Compared to the starting equimolar $\mathrm{As}(\mathrm{V})$ and $\mathrm{Fe}(\mathrm{III}$ concentrations, the dissolved As(III) concentrations were almost double of the dissolved Fe(II) concentration after bacterial reduction completed.

Decreasing the concentration of phosphate in the growth medium appeared to delay the release of both dissolved $\mathrm{Fe}(\mathrm{II})$ and As (III). In other words, for ANA-3, the 15 $\mu \mathrm{M}$ and for $\mathrm{CN} 32$, the $45 \mu \mathrm{M}$ phosphate concentration took longer to release iron and arsenic than those containing $400 \mu \mathrm{M}$ (Figs. 2 and 3). The highest plateau concentrations of $\mathrm{Fe}(\mathrm{II})$ and $\mathrm{As}(\mathrm{III})$ corresponded to the $15 \mu \mathrm{M}$ phosphate concentrations (Figs. 2 and 3).

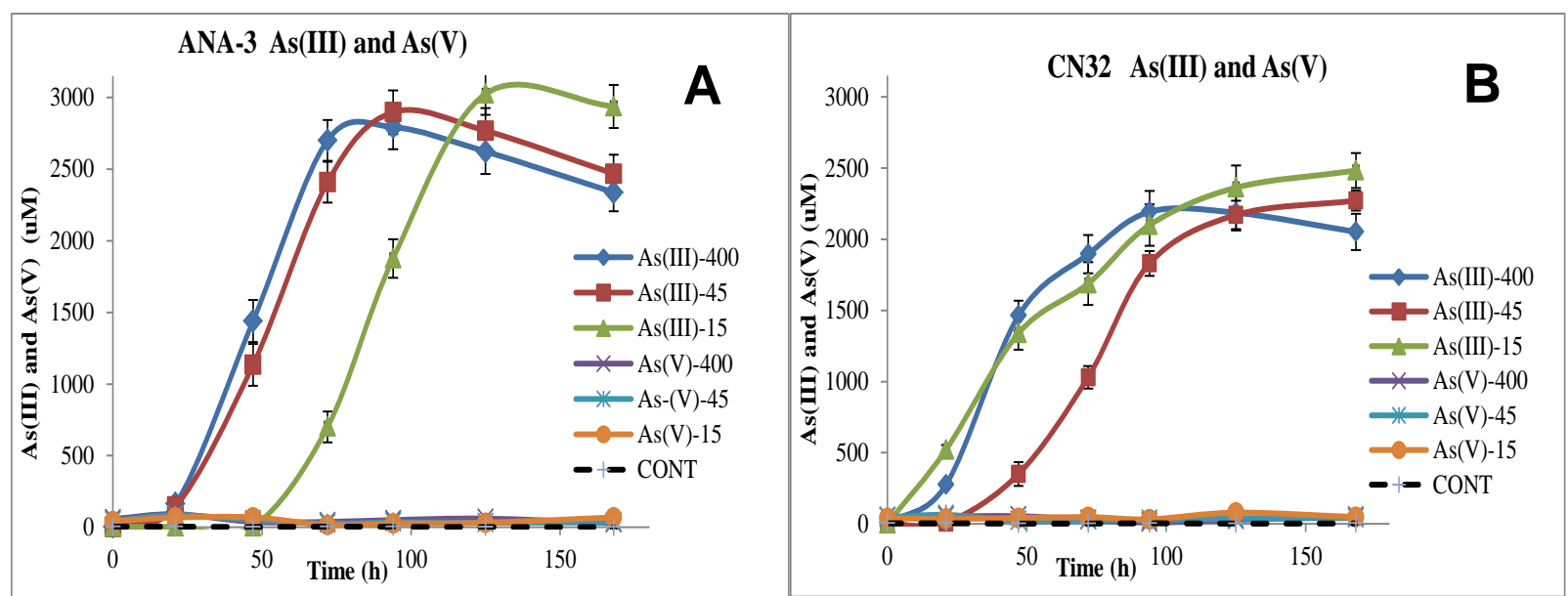


Figure 2. Release of dissolved $\mathrm{As}(\mathrm{III})$ and $\mathrm{As}(\mathrm{V})$ in the control and biotic systems (A) ANA-3 (B) CN32 in the presence of 400,45 and $15 \mu \mathrm{M}$ phosphate concentrations.

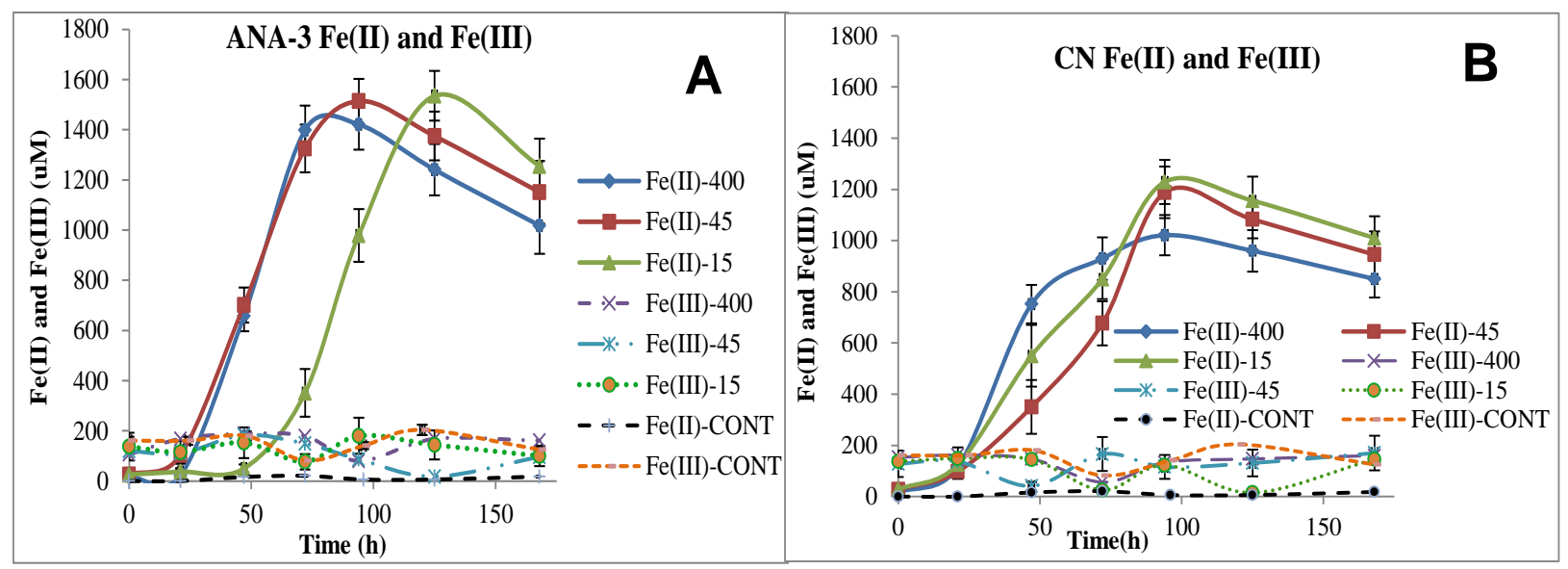

Figure 3. Release of dissolved $\mathrm{Fe}(\mathrm{II})$ and $\mathrm{Fe}(\mathrm{III})$ in the control and biotic systems (A) ANA-3 (B) CN32 in the presence of 400,45 and $15 \mu \mathrm{M}$ phosphate concentrations.

The effect of phosphate concentrations on the initial reduction rates

Initial rates of reduction determined from the initial linear section of the concentrationtime plots for kinetic runs, summarized in Table 1, increased with increased phosphate concentrations.

Table 1. Initial reduction rates with Shewanella sp. CN32 and Shewanella sp. ANA-3 at 15, 45 and $400 \mu \mathrm{M}$ phosphate concentrations.

\begin{tabular}{ccccc}
\hline $\begin{array}{c}\text { Phosphate } \\
\begin{array}{c}\text { Concentration } \\
(\mu \mathrm{M})\end{array}\end{array}$ & $\begin{array}{c}\text { CN32 } \\
\mathbf{A s}(\mathrm{III}) \\
(\boldsymbol{\mu M} / \mathbf{h})\end{array}$ & $\begin{array}{c}\text { CN32 } \\
\mathbf{F e}(\mathrm{II}) \\
(\mu \mathrm{M} / \mathbf{h})\end{array}$ & $\begin{array}{c}\text { ANA-3 } \\
\mathbf{A s}(\mathrm{III}) \\
(\boldsymbol{\mu M} / \mathbf{h})\end{array}$ & $\begin{array}{c}\text { ANA-3 } \\
\mathbf{F e}(\mathrm{II}) \\
(\boldsymbol{\mu M} / \mathbf{h})\end{array}$ \\
\hline 15 & $28.5 \pm 1.8$ & $14.7 \pm 0.7$ & $40.0 \pm 3.0$ & $23.3 \pm 2.3$ \\
45 & $31.7 \pm 2.4$ & $14.6 \pm 2.1$ & $44.3 \pm 3.0$ & $23.9 \pm 0.5$ \\
400 & $45.7 \pm 1.0$ & $24.2 \pm 0.5$ & $49.7 \pm 0.4$ & $27.0 \pm 1.5$ \\
\hline
\end{tabular}


Paired t-test calculations were used to determine if the differences in initial rates were statistically significant for different phosphate concentrations for a given bacterial species. Results of the t-tests with p-values are summarized in Tables S.2 for As(III) and S.3 for $\mathrm{Fe}$ (II) (Supplementary info). The initial rates were found to be statistically significantly different between $45 \mu \mathrm{M}$ phosphate and $400 \mu \mathrm{M}$ phosphate for both As(III) and $\mathrm{Fe}(\mathrm{II})$ for a given bacterial species, but not statistically significantly different between the $15 \mu \mathrm{M}$ and $45 \mu \mathrm{M}$ phosphate concentrations.

\section{Differences in reduction rates with bacterial species}

Paired t-test calculations were done to determine if differences in initial rates of reduction were statistically significantly different between the two bacterial species at a given phosphate concentration. Results of paired t-test with $p$ - values are summarized in Tables S.4 for As(III) and S.5 for Fe(II) (Supplementary info). The reduction rates were found to be statistically significantly different for the two bacterial species at a given phosphate concentration. Initial rates of reduction were higher for the ANA-3 than for the CN32 strain.

\subsection{Characterization of the pre- and post-reduction minerals}

\section{Bulk XRD analysis}

The background subtracted powder XRD spectra of the post-reduction samples, reduced with Shewanella sp. CN 32 (middle), and with Shewanella sp. ANA-3 (top) at $45 \mu \mathrm{M}$ phosphate concentrations, are shown in Figure 4. The XRD patterns indicate the presence of residual scorodite in the post reduction biotic samples. In addition, there are 
lower intensity peaks marked by arrows labelled "Ps" centered at $2 \theta$ values of $10.87^{\circ}$, $13.08^{\circ}$ and $29.67^{\circ}$ which correspond to parasymplesite. Furthermore, the low intensity peak centered at $2 \theta 8.3^{\circ}$ may suggest the presence of tooeleite in the reduced samples; however, this cannot be confirmed.

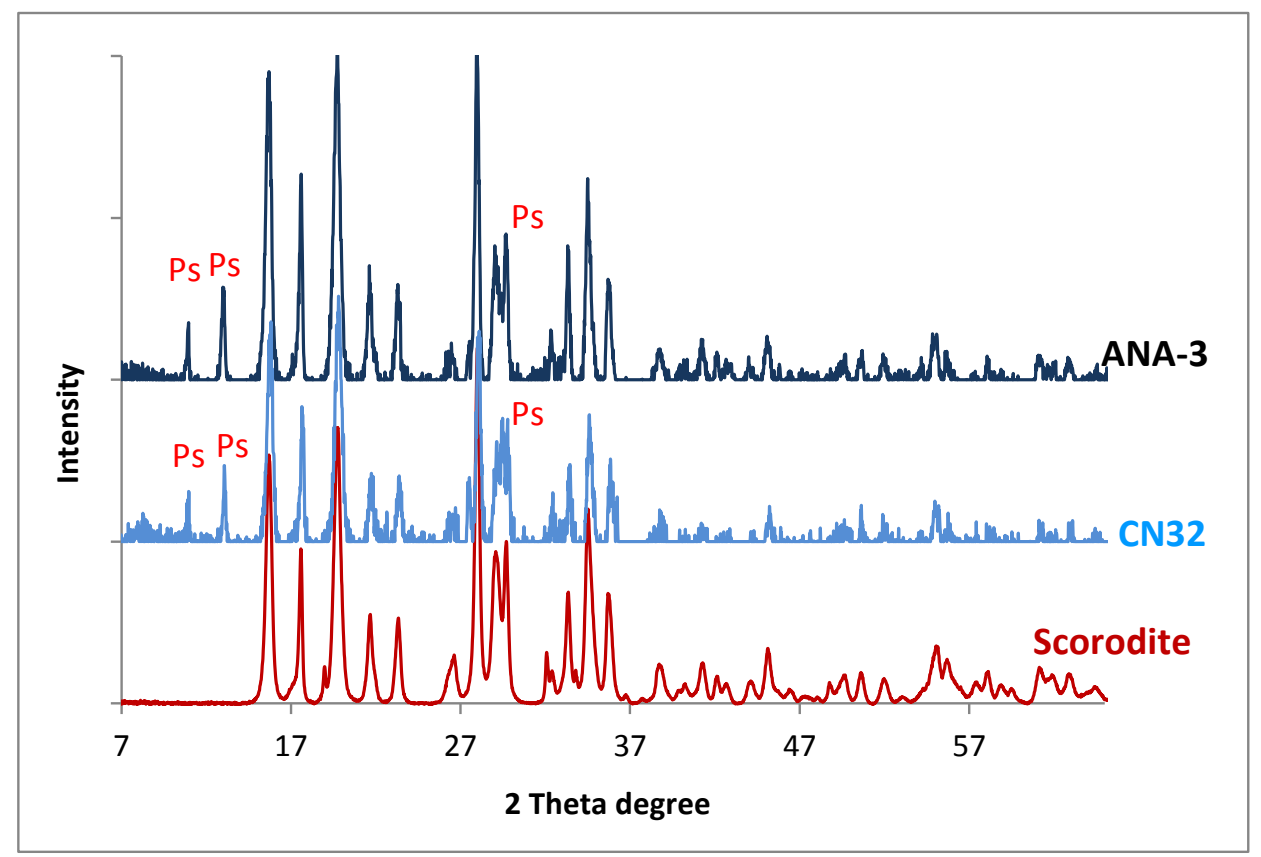

Figure 4. Background subtracted bulk XRD patterns of the scorodite control (CTN) and biotic ANA-3 and CN 32 reduced samples at $45 \mu \mathrm{M}$ phosphate concentration after 170 hours of reduction. Ps: parasymplesite.

\section{Electron microscopy analyses}

Field-emission SEM (FE-SEM) characterization of the post-reduction samples in the presence of both bacterial strains at various phosphate concentrations showed the presence of residual scorodite in the form of flaky particles after 120 hours of bacterial reduction (Figs. 5A and B) along with fine reduced particles. The biotic sample (Fig. 5A) for ANA-3 had less flaky material than the CN32 sample (Fig. 5B), which suggests that 
the ANA-3 sample may be more reduced. The flaky scorodite particles are visible in all of the post-reduction samples, along with the reduced particles (Figs. 5A and B).

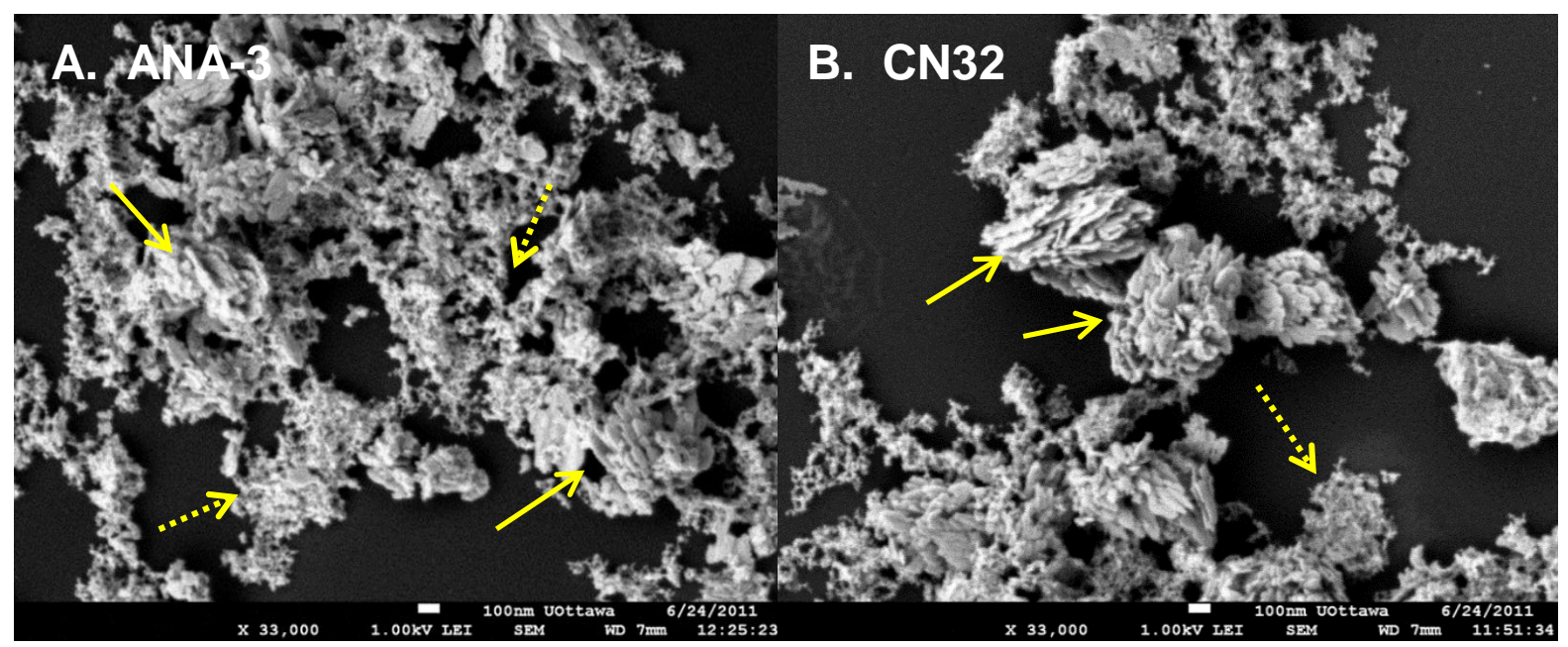

Figure 5. Field emission-SEM images of the biotic samples with (A) ANA-3 and (B) CN32 in the $400 \mu \mathrm{M}$ phosphate medium. Unreduced scorodite, flaky structures (arrows) and reduced structures (dotted arrows) were visible. The scale bar is $100 \mathrm{~nm}$.

TEM imaging of the post reduction material (Fig. 6A) showed that it contained up to $20 \%$ more arsenic than iron. HRTEM observations of the same material indicated that it was amorphous (Fig. 6B) suggesting the presence of some biogenic material. HRTEM imaging (Fig. 6B) of the area labelled by the arrow shown on Fig. 6A, revealed an amorphous structure without features reassembling lattice fringes. The selected area electron diffraction (SAED) patterns (Fig. 6B) also suggest an amorphous structure resulting from bacterial reduction. 


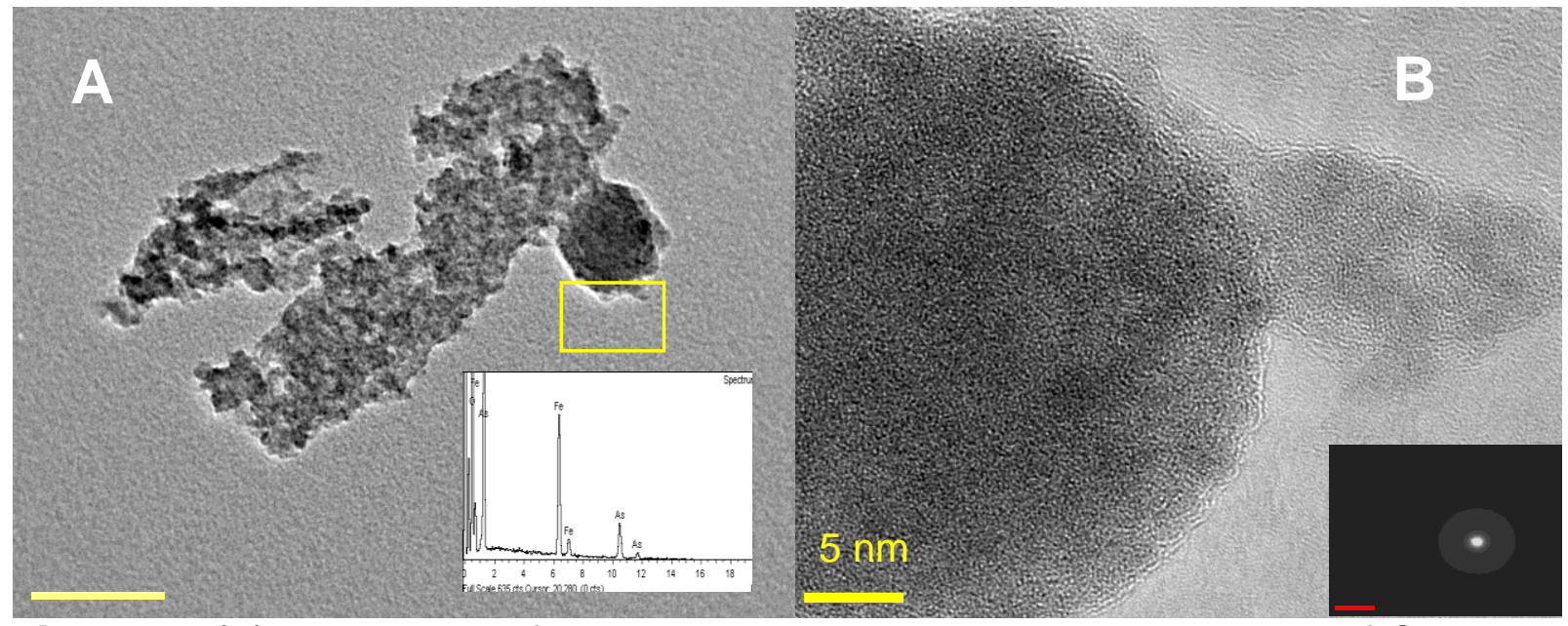

Figure 6. (A) TEM image of the post reduction sample in the presence of CN32 at 45 $\mu \mathrm{M}$ phosphate medium after 170 hours. Inset: energy-dispersive spectrum collected from the particle showing the proportions of Fe and As. (B) HRTEM of the region marked in (A). Inset is the selected area electron diffraction (SAED).

$X$-ray absorption (XAFS) spectroscopy:

The X-ray fluorescence maps of As(III) and As (V) of the post reduction samples show distinct areas of high As(III) concentration that are non-uniform or spatially heterogeneous (Fig. 7) for both bacteria at all phosphate concentrations. The As K-edge XANES spectra were collected from such areas to identify the $\mathrm{As}(\mathrm{III})$ and $\mathrm{As}(\mathrm{V})$ species (Fig. 7E). The spectrum of original scorodite was used as a reference.

Spectrum \#1 on Figure 7E of the As(III) species in the biogenic Fe(II)-As(III) resulting from microbial reduction of ferrous arsenate in the presence of Shewanella sp. ANA-3 resembles the spectrum obtained by Babechuk et al (2009). The small hump to the right of the $\mathrm{As}(\mathrm{III})$ peak corresponds to $\mathrm{As}(\mathrm{V})$ (spectrum \#4) from the contribution of the nearby unreduced scorodite. Spectrum \#4 is similar to that of scorodite. Spectrum \#2 and \#3 are mixtures between scorodite (\#4) and the newly formed arsenite species. 


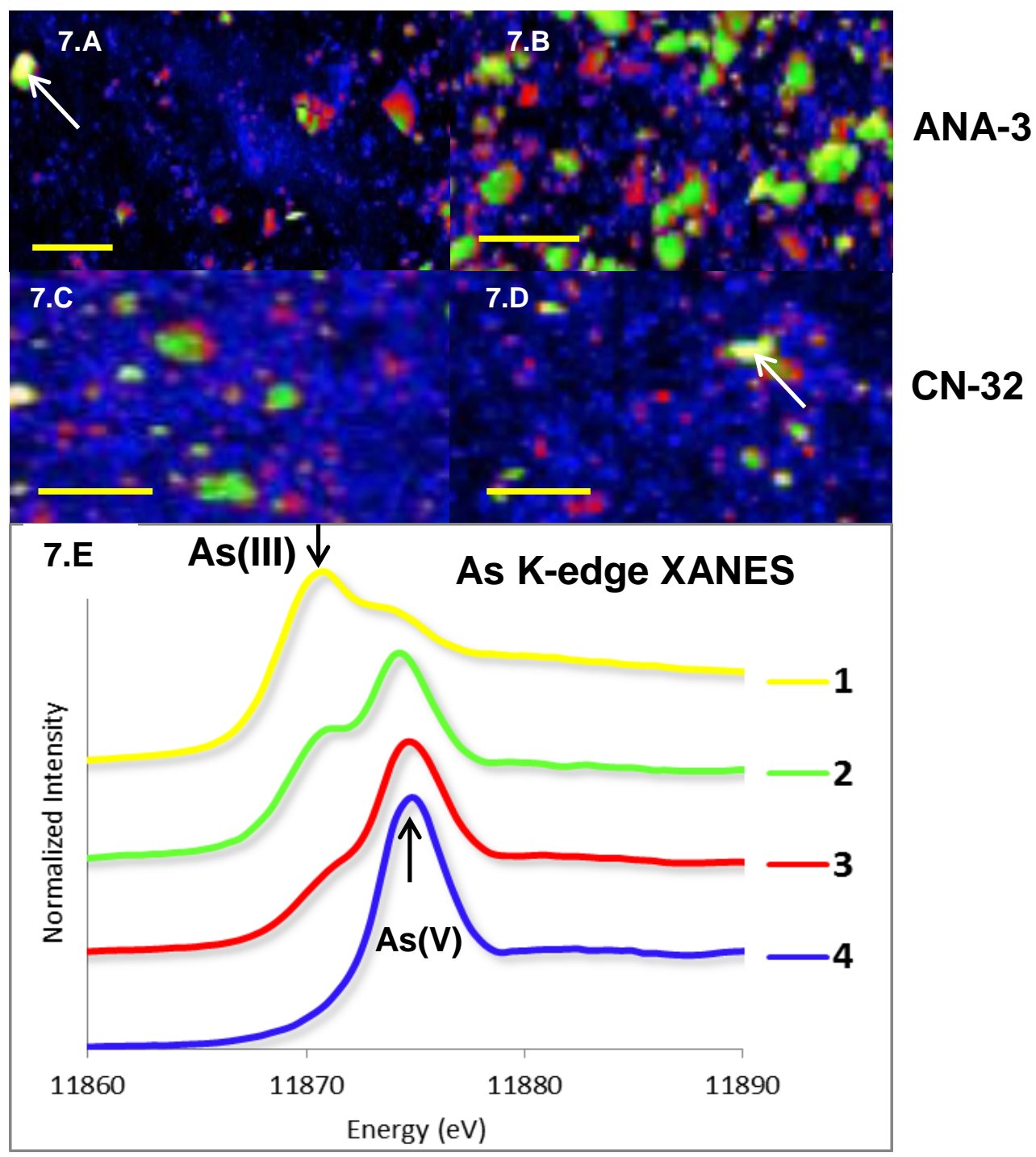

Figure 7. Arsenic X-ray fluorescence maps showing the spatial distribution of As(III) (yellow) and $\mathrm{As}(\mathrm{V})$ (blue) in the biotic solid samples. (A, B) ANA-3 and (C, D) CN32, at $45 \mu \mathrm{M}$ phosphate medium. The high As(III) domains are marked by arrows in A and B. Scale bars: $~ 350 \mu \mathrm{m}$. E: Normalized As K-edge XANES spectra collected from a high As(III) domain (1), mixed $\mathrm{As}(\mathrm{III})$ and $\mathrm{As}(\mathrm{V})$ domains (2, 3), and a high $\mathrm{As}(\mathrm{V})$ region(4).

Normalized As K-edge XANES spectra of the post reduction solid samples of ANA-3 and CN32 at all phosphate concentrations are shown in Fig. 8A. The As(III) 
peaks are, in general, more prominent for the ANA-3 than for $\mathrm{CN} 32$, and this observation is more apparent in the direct comparison between the two strains at the same phosphate concentrations (Fig. 9).
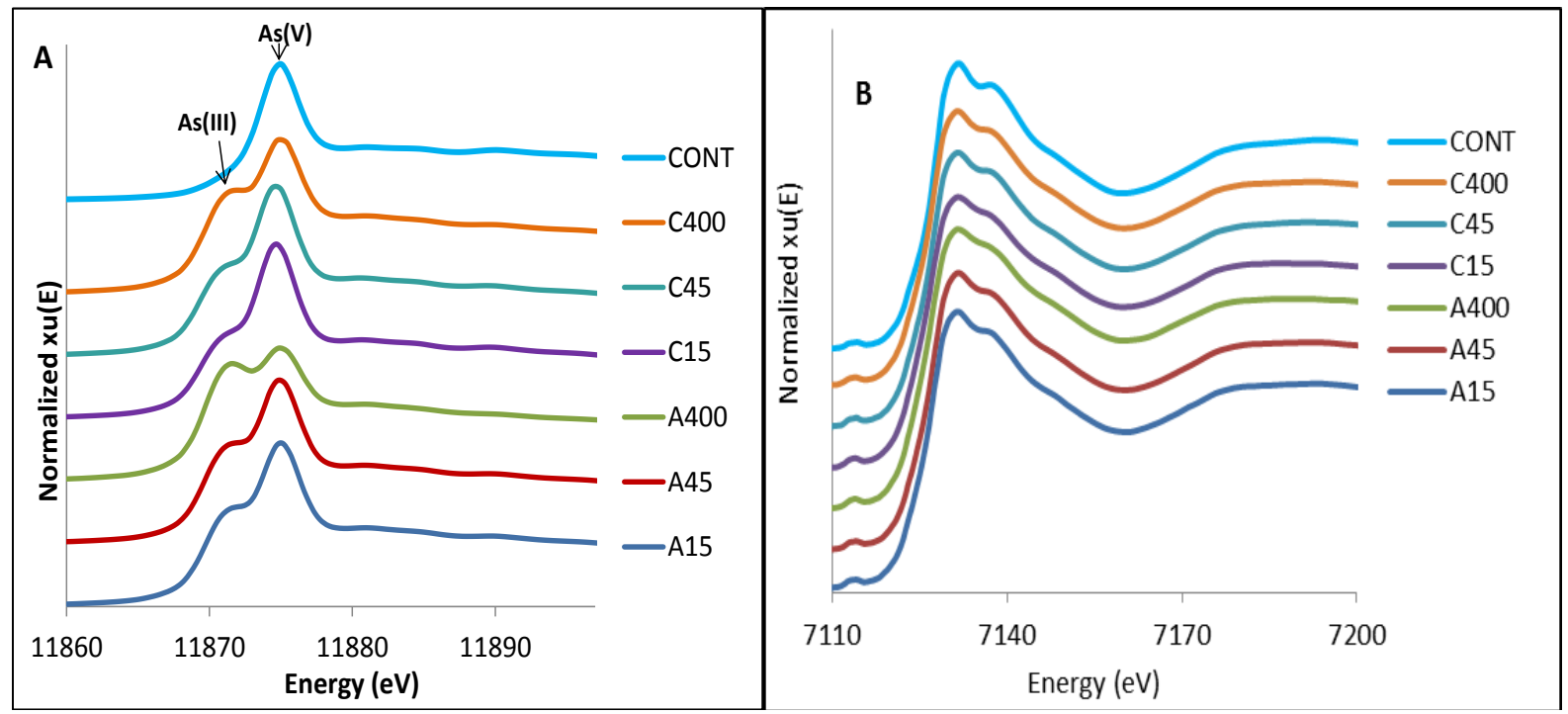

Figure 8. (A) The normalized As K-edge XANES spectra of the solid samples at 15, 45 and $400 \mu \mathrm{M}$ phosphate concentrations and controls, labelled as A15, A45, A400 for ANA-3 and C15, C45 and C400 for CN32 and CONT for controls. (B) The normalized Fe K-edge XANES spectra for the same samples.
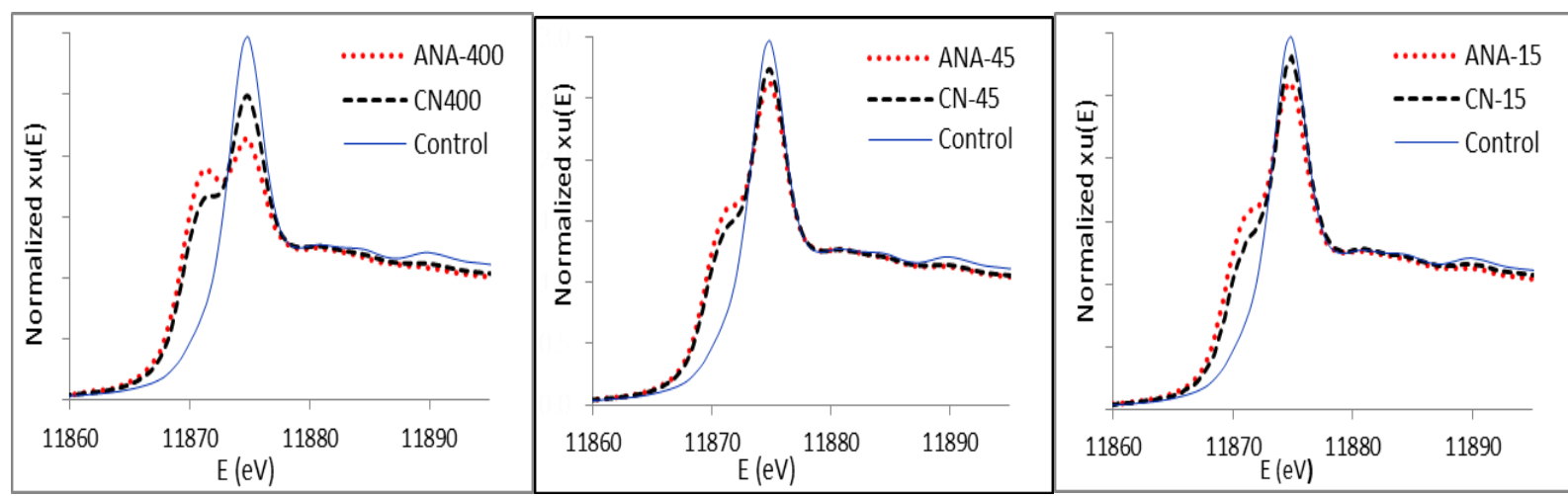

Figure 9. The normalized As K-edge XANES spectra of the biotic reduction products of ANA-3 and CN32 paired at 400, 45 and $15 \mu \mathrm{M}$ phosphate concentrations with the abiotic scorodite control. 
The Fe K-Edge XANES spectra of the reduced samples at al I phosphate concentrations are similar and resemble the spectrum of the abiotic control (Fig. 8B).

The proportions of arsenic species in the reduced samples were determined by least-squares fitting (Paktunc, 2003 and 2004) using over 20 inorganic and organic arsenic reference compounds. Since no parasymplesite reference spectrum was available, it could not be used for the least-squares fitting. The best fits were found with biogenic Fe(II)-As(III) compound, tooeleite (Morin et al. 2003 and 2007) and the abiotic scorodite control, however the presence of tooeleite could not be confirmed and therefore removed from the list of reference compounds. The normalized As K-edge XANES fitting results of the As(III) listed in Table 3, indicate that the reduced samples are composed of 24 to $60 \%$ scorodite, 40 to $76 \%$ biogenic Fe(II)-As(III) depending on the bacterial strain and phosphate concentrations used for the reduction.

Table 3. Proportions of arsenic species in the solid residues obtained by least squares fitting of the normalized As K-edge XANES spectra.

\begin{tabular}{lllllll}
\hline Compound & CN15 & CN45 & CN400 & ANA15 & ANA45 & ANA400 \\
\hline Scorodite & 0.599 & 0.542 & 0.408 & 0.526 & 0.534 & 0.241 \\
Fe(II)As(III)** & 0.401 & 0.458 & 0.592 & 0.474 & 0.466 & 0.759 \\
R-Factor & 0.00195 & 0.00543 & 0.00524 & 0.00195 & 0.00322 & 0.00826 \\
\hline
\end{tabular}

${ }^{*}$ Parasymplesite reference spectrum was not available for least squares fitting.

**Biogenic ferrous arsenite compound (Weisener et al. 2011).

Least-squares fitting of the $\mathrm{k}^{3}$-weighted As K-edge EXAFS spectra, performed in the range of 3-14 $\AA^{-1}$ produced similar results (Table 4 and Fig. 10B) to those of the XANES spectra (Table 3, Fig. 10A). 
Table 4. Fractional compositions of arsenic in the reduced biotic samples obtained from $k^{3}$-weighted EXAFS least-squares fitting results.

\begin{tabular}{lllllll}
\hline Compound & CN15 & CN45 & CN400 & ANA15 & ANA45 & ANA400 \\
\hline Scorodite & 0.653 & 0.617 & 0.425 & 0.510 & 0.511 & 0.298 \\
Fe(II)As(III) ${ }^{\star *}$ & 0.347 & 0.383 & 0.575 & 0.490 & 0.489 & 0.702 \\
R-Factor & 0.0213 & 0.0352 & 0.0407 & 0.0274 & 0.0292 & 0.0524 \\
\hline
\end{tabular}

${ }^{*}$ Parasymplesite reference spectrum was not available for least squares fitting.

${ }^{* * B}$ Biogenic ferrous arsenite compound (Weisener et al. 2011).

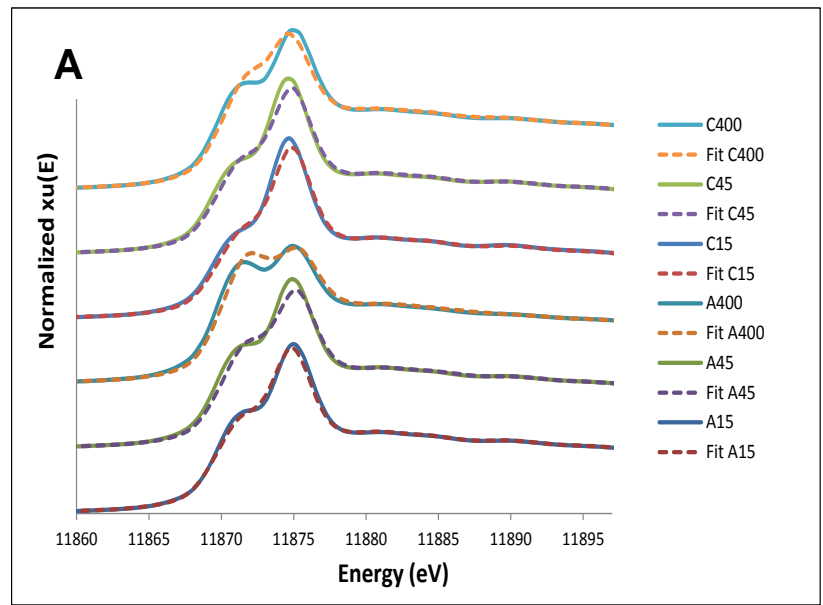

B

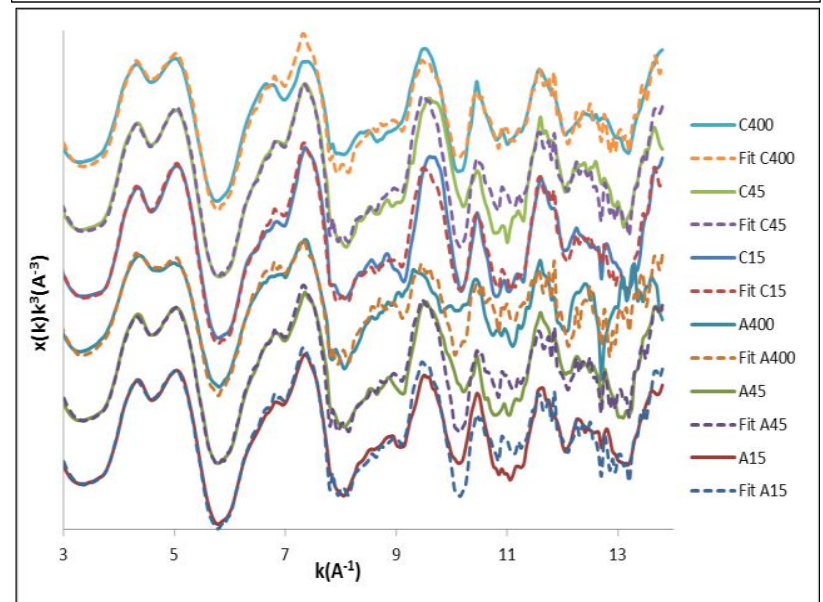

Figure 10. Least-squares fitting of the normalized As K-edge XANES spectra (A) and $\mathrm{k}^{3}$-weighted As K-edge EXAFS spectra (B). Experimental spectra are shown in solid 
lines and the fits by dotted lines. A in the sample labels stands for ANA-3 and C for CN32, followed by the phosphate concentration.

\section{Discussion}

In comparing the two bacterial strains, it was found that the initial rates of reduction and the plateau concentrations of the dissolved reduced species, $\mathrm{Fe}$ (II) and As(III), were greater for the Shewanella sp. ANA-3 than for Shewanella putrefaciens CN32. These results suggest that Shewanella sp. ANA-3 is more efficient at reducing iron and arsenic than the CN32 is under the conditions used in these experiments. The question arises as to why the two strains of bacteria have different reducing efficiencies. The epigenetics, including experimental growth conditions, are known to control the expression of the cell membrane proteins. More specifically, phosphorylation of the membrane and other proteins are crucial for cellular signaling which is part of the sensory system for detecting the environmental conditions which also regulates cell adhesion, quorum sensing (Miller-Bassler, 2001), and motility (Mijakovic, 2010). Both strains were grown in the same low phosphate medium during the growth phase. Murray and Saltikov (2007), who analyzed the genome sequence of Shewanella putrefaciens strain $\mathrm{CN}-32$, demonstrated that the $\operatorname{arr} A B$ gene cluster, which is responsible for arsenate reduction, is identical to the $\operatorname{arr} A B$ of Shewanella sp. strain ANA-3. Both strains are believed to respire arsenate via very similar mechanisms. A possible explanation for the differences of reduction efficiencies could be that CN32 is more sensitive than ANA-3 to the experimental growth conditions i.e. low phosphate concentrations, such as those used in this research. Future research should investigate 
the fitness of CN32 when grown at very low phosphate concentrations for long periods of time to see if it can really adapt to the conditions and still efficiently reduce Fe and As while growing. The findings would be relevant to As-contaminated environments, such as mining residues, where phosphate levels can be low.

With respect to the effect of the phosphate concentration on the reduction rates, it was found that the initial rates of reaction were greatest at the highest phosphate concentration for both bacteria. Our results are in agreement with the study of Saltikov et al. (2005) who studied the effect of phosphate on Shewanella sp. ANA-3 using 100 $\mu \mathrm{M}, 600 \mu \mathrm{M}$, and $5 \mathrm{mM}$ inorganic phosphate. The authors found that high concentrations of phosphate promoted more robust growth of ANA-3 on $\mathrm{As}(\mathrm{V})$. In our study, the highest initial rates were observed with the $400 \mu \mathrm{M}$ phosphate concentrations, which may be due to the greater bioavailability of phosphate at this concentration. The bioavailability of phosphate is decreased by the amount that is adsorbed onto the surface of solids or precipitated as secondary minerals. Phosphate diffuses into the interior of the bacterial cell membranes of Gram negative bacteria, such as Shewanella, through transmembrane $\beta$-barrel protein channels or porins (Luckey, 2008a). The bacteria require soluble inorganic phosphate, but the adsorbed or precipitated inorganic phosphate is relatively inaccessible. Low phosphate concentrations can limit bacterial growth, which may only allow survival of the cells but not their growth as shown by the decrease in log CFU counts with time (Figure 1). High soluble arsenic concentration, compared to phosphate, may have also induced toxic effects on the bacteria and further retarded their growth. Saltikov et al. (2005) reported that during the early growth phases, ANA-3 preferentially uses the respiratory pathway 
instead of the detoxification pathway because transcription of the ars operon is blocked. As time progresses, the need to secrete As(III) increases as As(III) accumulates to toxic concentrations, and ANA-3 turns on the ars operon. Detoxification likely happened during scorodite reduction since the $\mathrm{As}(\mathrm{III})$ concentration reached over $1 \mathrm{mM}$. Our results indicated that the log of colony forming units (CFU) versus time (Fig.1B) showed no bacterial growth, indicating that the cells were only maintaining themselves.

The observed effect of phosphate on the plateau concentrations of reduced species is consistent with the studies of Fredrickson et al. (1998), Kukkadapu et al., (2004) and Borch et al. (2007) who reported that increasing phosphate concentrations correlated with decreased $\mathrm{Fe}(\mathrm{II})$ in solution as a result of vivianite formation. The results of our calculations using PHREEQC (Tables S.6 and S.7), indicate that the biotic systems at the end of the reduction experiments were indeed saturated with respect to vivianite, with the greatest saturation indices at the $400 \mu \mathrm{M}$ phosphate concentrations. However, vivianite was not detected in the post reduction samples. The plateau concentration of dissolved As(III) was appreciably greater than the dissolved Fe(II) concentration in all experiments for both strains (Fig.2), because under the experimental conditions used, some of the $\mathrm{Fe}(\mathrm{II})$ precipitated as a biogenic $\mathrm{Fe}(\mathrm{II})-\mathrm{As}(\mathrm{III})$ compound (Fig.6B) and parasymplesite.

The normalized relative peak intensities of $A s(I I I)$ to $A s(V)$ in the As XANES spectra (Figs. 8 and 9) of the solid samples are greater for the Shewanella sp. ANA-3 than for CN32, and similarly for the arsenic fitting results (Fig.10A and B). The results of this study indicate that Shewanella sp. ANA-3 is more efficient than Shewanella sp CN32 in reducing scorodite under the conditions of this experiment. SEM 
characterization revealed that the ANA-3 systems appeared to show more reduced material. The results are also supported by the SEM images showing the presence of bacterial colonies on the surfaces of the solid particles while their absence in the subcultured clear solution suggest that the bacteria must be directly attached to scorodite surfaces for reductive dissolution to occur.

Our research clearly shows that bacterial reduction of scorodite led to the release of mobile and toxic dissolved As(III) into the aqueous phase. Drewniak et al. (2008) found that there are many strains of bacteria in the mining environment that can reduce $\mathrm{As}(\mathrm{V})$. Chatain et al., (2005) found that under anaerobic conditions (at $\mathrm{pH} \sim 7$ ) indigenous bacterial activity can release arsenic from a contaminated mining soil. Kocar et al. (2010) reported that in the presence of sulfate reducing bacteria, sulfide can also reduce ferrihydrite and arsenate. These studies show that $A s(V)$ reduction is likely to happen in the environment and that the presence of stable $\mathrm{As}(\mathrm{V})$ minerals, such as scorodite, might undergo reduction and release some toxic soluble As(III), especially in environments where anoxic conditions prevail. Our findings should therefore be taken into consideration for mine wastes rich in scorodite. As shown by the abiotic control experiments, scorodite remains to be stable under anaerobic condition and circumneutral $\mathrm{pH}$. Under these conditions the presence of bacteria, which are both dissimilatory iron and arsenic reducers, results in the reductive dissolution of scorodite with the formation of significantly higher concentrations (by at least a factor of 10 ) of dissolved arsenic than in the abiotic systems, mainly in the form of the more bioavailable and more soluble As(III) species. The severe negative consequence of the effect of such bacterial activity brings into question the effectiveness of scorodite in the 
stabilization of arsenic along with other factors discussed by Paktunc et al. (2015) . The influence of bacteria on the stability of scorodite must therefore be taken into consideration in designing mine waste management and disposal options.

\section{Summary and Conclusion}

In this research, we found that both Shewanella putrefaciens CN32 and ANA-3 caused the reductive dissolution of scorodite, and that ANA-3 was more efficient. Higher phosphate concentrations increased the initial rate of reduction for both strains, whereas the plateau concentrations of the dissolved $\mathrm{As}(\mathrm{III})$ and $\mathrm{Fe}(\mathrm{II})$ were higher at the lowest phosphate concentrations. In these experiments, the concentrations of the dissolved As(III), the more bioavailable and toxic form of arsenic, was about twice the concentrations of the dissolved $\mathrm{Fe}(\mathrm{II})$. The post-reduction secondary solids included the biogenic $\mathrm{Fe}(\mathrm{II})-\mathrm{As}(\mathrm{III})$ compound and parasymplesite. Our findings have important implications on the management of mine wastes containing scorodite especially if artificial or natural covers are installed on mining residues, which can favor the development of reducing conditions conducive to the growth and survival of $\mathrm{Fe}$ and As reducing bacteria.

\section{Acknowledgements}

This project was partially funded by NSERC Discovery grants to D.F. and D.P. and by CANMET. We kindly thank C. Saltikov for providing the Shewanella sp. ANA-3 strain, D. Smith at CANMET for XRD and Y. Liu at the University of Ottawa's Centre for Catalysis Research and Innovation (CCRI) for the FE-SEM/TEM and HRTEM imaging, 
and R. Gordon for the X-ray absorption spectroscopy experiments. The experiments at the Pacific Northwest Consortium-Collaborative Access Team's (PNC/XOR) beamline of the Advanced Photon Source (APS) were carried out under a General User Proposal to DP and a Partner User Proposal supported by the Natural Sciences and Engineering Research Council (NSERC) of Canada through a major facilities access grant. Argonne National Laboratory is supported by the US Department of Energy under Contracts W31-109-Eng-38 (APS) and DE-FG03-97ER45628 (PNC-CAT).

\section{References:}

Amstaetter, K., Borch, T., Kappler, A., 2012. Influence of humic acid imposed changes of ferrihydrite aggregation on microbial Fe(III) reduction, Geochim. Cosmochim. Acta 85, 326-341.

Borch, T., Masue, Y., Kukkadapu, R.K., Fendorf, S., 2007. Phosphate imposed limitations on biological reduction and alteration of ferrihydrite. Environ. Sci. Technol. 41, 166-172.

Cavalca, L., Corsini, A., Zacheo, P., Andreoni, V., Muyzer, G., 2013. Microbial transformation of arsenic: prespectives for biological removal of As from water. Future Microbiol. 8, 753-768.

Chatain, V., Bayard, R., Sanchez, F., Moszkowicz, P., Gourdon, R., 2005. Effect of indigenous bacteria activity on arsenic mobilization under anaerobic conditions. Environ. Int. 31, 221-226.

Cummings, D.E., Caccavo, F., Fendorf, S., Rosenzweig, R.F., 1999. Arsenic mobilization by the dissimilatory Fe(III)-reducing bacterium Shewanella alga BrY. 
Environ. Sci. Technol. 33, 723-729.

Corriveau, M.C., Jamieson, H.E., Parsons, M.B., Hall, G.E.M., 2011. Mineralogical characterization of arsenic in gold mine tailings from three sites in Nova Scotia. Geochem. Explor. Environ. Anal. 11, 179-192.

Dhar, R.K., Zhenga, Y., Rubenstonec, J., van Geenc, A., 2004. A rapid colorimetric method for measuring arsenic concentrations in groundwater. Anal. Chim. Acta 526, 203-209.

Drewniak, L., Matlakowska, R., Sklodowska, A., 2008. Arsenic-Hypertolerant Pseudomonads Isolated from Ancient Gold and Copper-Bearing Black Shale Deposits. Geomicrobiol. J. 25:357-362.

Drewniak, L., Matlakowska, R., Sklodowska, A., 2009. Microbial impact on arsenic mobilization in Zloty Stok gold mine. Adv. Mat. Res. 71-73, 121-124.

Drewniak, L., Matlakowska, R., Rewerski, B., Sklodowska, A., 2010. Arsenic release from gold mine rocks mediated by the activity of indigenous bacteria. Hydrometallurgy 104, 437-442.

Fredrickson, J.K., Zachara, J.M., Kennedy, D.W., Dong, H., Onstott, T.C., Hinman, N.W., Li, S-M., 1998. Biogenic iron mineralization accompanying the dissimilatory reduction of hydrous ferric oxide by a groundwater bacterium. Geochim. Cosmochim. Acta, 62, 3239-3257.

Glasauer, S., Weidler, P. G., Langley, S., Beveridge, T.J., 2003. Controls on Fe reduction and mineral formation by a subsurface bacterium. Geochim. Cosmochim. Acta 67, 1277-1288. 
Harvey, M.C., Schreiber, M.E., Rimstidt, D.J., Griffith, M.M., 2006. Scorodite dissolution kinetics: Implications for arsenic release. Environ. Sci. Technol. 40, 6709-6714. Johnson, D.L., Pilson, M.E.Q., 1972. Spectrophotometric determination of arsenite, arsenate and phosphate in natural waters. Anal. Chim. Acta 58, 289-299.

Kocar, B.D., Borch, T., Fendorf, S., 2010. Arsenic mobilization and repartitioning during biogenic sulfidization and transformation of ferrihydrite. Geochim. Cosmochim. Acta $74,980-994$.

Krause, E., Ettel, V.A., 1989. Solubilities and stabilities of ferric arsenates. Hydrometallurgy 22, 311-337.

Kukkadapu, R.K., Zachara. J.M., Fredrickson. J.K., Kennedy, D.W., 2004. Biotransformation of two-line silicaferrihydrite by a dissimilatory Fe(III)-reducing bacterium: Formation of carbonate green rust in the presence of phosphate. Geochim. Cosmochim. Acta 68, 2799-2814.

Langley, S., Gault, A.G., Ibrahim, A., Renaud, R., Fortin, D., Clark, I.D., Ferris, F.G., 2009. A comparison of the rates of $\mathrm{Fe}(\mathrm{III})$ reduction in synthetic and bacteriogenic iron oxides by Shewanella putrefaciens CN32. Geomicrobiol. J. $26,57-70$.

Langmuir, D., Mahoney, J., Rowson, J., 2006. Solubility products of amorphous ferric arsenate and crystalline scorodite $\left(\mathrm{FeAsO}_{4} \cdot 2 \mathrm{H}_{2} \mathrm{O}\right)$ and their application to arsenic behaviour in buried mine tailings, Geochim. Cosmochim. Acta 70, 29422956. 
Langmuir, D. Mahoney, J. MacDonald, A. Rowson, J., 1999, Predicting arsenic concentrations in the porewaters of buried uranium mill tailings. Geochim. Cosmochim. Acta 63, 3379-3394.

Liao, V.H.-C., Chu, Y.J., Su, Y.C., Hsiao, S.Y., Wei, C.C., Liu, C.W., Liao, C.M., Shen, W.C., Chang, F.j., 2011. Arsenite-oxidizing and arsenate-reducing bacteria associated with arsenic-rich groundwater in Taiwan. J. Contam. Hydrol. 123, 2029.

Lovely, D.R., 2001. Anaerobes to the rescue. Science 293, 1444-1446.

Luckey, M., 2008. Membrane structural biology. Cambridge University Press., New York, USA, p:120.

Macur, R.E., Jackson, C.R., Botero, L.M., McDermott, T.R., Inskeep, W.P., 2004. Bacteria populations associated with the oxidation and reduction of arsenic in an unsaturated soil. Environ. Sci. Technol. 38, 104-111.

Majzlan, J., Drahota, P., Filippi, M., Grevela, K-D., Kahld, W-A., Plášil, J., BoerioGoates, J., Woodfield. B.F., 2012. Thermodynamic properties of scorodite and parascorodite $\left(\mathrm{FeAsO}_{4} \cdot 2 \mathrm{H}_{2} \mathrm{O}\right)$, kaňkite $\left(\mathrm{FeAsO}_{4} \cdot 3.5 \mathrm{H}_{2} \mathrm{O}\right)$, and $\mathrm{FeAsO}_{4}$, Hydrometallurgy 117-118, 47-56.

Miller, M.B., Bassler, B.L., 2001. Quorum sensing in bacteria. Annu. Rev. Microbiol. 55, 165-99.

Mijakovic, I., 2010. Protein Phosphorylation in Bacteria. Microbe magazine, 5, 21-25.

Morin, G., Juillot, F., Casiot, C., Bruneel, O., Personné, J. C., Elbaz-Poulichet, F., Leblanc, M., Ildefonse, P., Cala, G., 2003. Bacterial formation of tooeleite and 
mixed $\mathrm{As}^{3+} /(\mathrm{V})-\mathrm{Fe}^{3+}$ gels in the Carnoules acid mine drainage, France. A XANES, XRD, and SEM study. Env. Sci. Tech. 37, 1705-1712.

Morin, G., Rousse, G., Elkaim, E., 2007. Crystal structure of tooeleite, $\mathrm{Fe}_{6}\left(\mathrm{AsO}_{3}\right)_{4} \mathrm{SO}_{4}(\mathrm{OH})_{4} \cdot 4 \mathrm{H}_{2} \mathrm{O}$, a new iron arsenite oxyhydroxysulfate mineral relevant to acid mine drainage. Am. Mineral. 92, 193-197.

Murphy, J.N., Saltikov, C.W., 2007. The cymA gene, encoding a tetraheme c-type cytochrome, is required for arsenate respiration in Shewanella species. J. Bacteriol. 189, 2283-2290.

Newman, D.K., Kennedy, K., Coates, J.D., Ahmann, D., Ellis, D.J., Lovley, D.R., Morel, F. M. M., 1997. Dissimilatory arsenate and sulfate reduction in Desulfotomaculum auripigmentum sp. nov. Arch. Microbiol. 168, 380-388.

Newman, D.K., Ahmann, D., Morel, F.M.M., 1998. A brief review of microbial arsenate respiration. Geomicrobiol J. 15, 255-268.

Oremland, R.S., Stolz, J.F, 2005. Arsenic, microbes and contaminated aquifers. Trends in Microbiology13, 45-49.

Paktunc, D., 2004. A computer program for analysing complex bulk XAFS spectra and for performing significance tests. J. Synchrotron Rad. 11, 295 - 298

Paktunc, D., 2008a. Speciation of Arsenic in Pyrite by Micro-X-Ray Absorption Fine-Structure Spectroscopy (XAFS). Ninth International Congress for Applied Mineralogy Brisbane, QLD, Australia, 8 - 10 September.

Paktunc, D., 2008b. Speciation of arsenic in an anaerobic treatment system at a $\mathrm{Pb}-\mathrm{Zn}$ smelter site, gold roaster products, Cu smelter stack dust and impacted soil. The AusIMM. 8, 343-348. 
Paktunc, D., Bruggeman, K., 2010. Solubility of nanocrystalline scorodite and amorphous ferric arsenate: Implications for stabilization of arsenic in mine wastes, Appl. Geochem. 25, 674-683

Paktunc, D., Foster, A., Laflamme, G., 2003. Speciation and Characterization of Arsenic in Ketza River Mine Tailings Using X-ray Absorption Spectroscopy. Env. Sci. Technol. 37, 2067-2074.

Paktunc, D., Foster, A., Heald, S., Laflamme, G., 2004. Speciation and characterization of arsenic in gold ores and cyanidation tailings using X-ray absorption spectroscopy. Geochim. Cosmochim. Acta 68, 969-83.

Paktunc, D., Dutrizac, J., Gertsman, V., 2008. Synthesis and phase transformations involving scorodite, ferric arsenate and arsenical ferrihydrite: Implications for arsenic mobility. Geochim. Cosmochim. Acta 72, 2649-2672

Paktunc, D., Majzlan, J., Huang, A., Thibault, Y., Johnson, M.B., White, M.A., 2015. Synthesis, characterization and thermodynamics of arsenates forming in the Ca$\mathrm{Fe}(\mathrm{III})-\mathrm{As}(\mathrm{V})-\mathrm{NO}_{3}$ system: Implications for the stability of Ca-Fe arsenates. Am. Mineral. 100, 1803-1820.

Papassiopi, N., Vaxevanidou, K., Paspaliaris, I., 2003. Investigating the use of iron reducing bacteria for the removal of arsenic from contaminated soils. Water, Air, \& Soil Poll.: Focus 3, 81-90.

Parkhurst, D.L., Appelo, C.A.J., 1999. User's guide to PHREEQC (Version 2), A computer program for speciation, batch reaction, one-dimensional transport, and inverse geochemical calculation. U.S. Geol. Surv. Water-Resource Invest. Rep. 99-4259. 
Pepper, S.E., Borkowski, M., Richmann, M.K., Reed, D.T., 2010. Determination of ferrous and ferric iron in aqueous biological solutions. Anal. Chim. Acta. 663, 172-177.

Praharaj, T., Fortin, D., 2008. Seasonal variations of microbial sulfate and iron reduction in alkaline $\mathrm{Pb}-\mathrm{Zn}$ mine tailings (Ontario, Canada). Appl. Geochem. 23, 37283740.

Ravel, B. Newville, M., 2005. ATHENA, ARTEMIS, HEPHAESTUS: data analysis for Xray absorption spectroscopy using IFEFFIT. J. Synchrotron Rad. 12, 537-541.

Saltikov, C.W., Wildman, R.A. Jr., Newman, D.K., 2005. Expression Dynamics of Arsenic Respiration and Detoxification in Shewanella sp. Strain ANA-3. J. Bacteriol. 187, 7390-7396.

Shen, S., Li, X-F., Cullen, W.R., Weinfeld, M., Le, C.X., 2013. Arsenic binding to proteins. Chem. Rev. 113, 7769-7792

Smedley, P.L., Kinniburgh, D.G., 2002. A review of the source, behavior and distribution of arsenic in natural waters. Appl. Geochem. 17, 517-568.

Stolz, J.F., Basu, P., Santini, J.M., Oremland, R.S., 2006. Arsenic and Selenium in Microbial Metabolism. Annu. Rev. Microbiol., 60, 107-130.

Stookey, L.L., 1970. Ferrozine, a new spectrophotometric reagent for iron: Anal. Chem. 42, 779-781.

Viollier, E., Inglett, P.W., Hunter, K., Roychoudhury, A.N., Van Cappellen, P., 2000. The ferrozine method revisited: $\mathrm{Fe}(\mathrm{II}) / \mathrm{Fe}(\mathrm{III})$ determination in natural waters. App. Geochem., 15, 785-790. 
Walker, S.R., Parsons, M.B., Jamieson, H.E., Lanzirotti, A., 2009. Arsenic mineralogy of near-surface tailings and soils: influences on arsenic mobility and bioaccessibility in the Nova Scotia gold mining districts. Can. Mineral. 47, 533-556.

Weisener, C.G., Guthrie, J.W., Smeaton, C.M., Paktunc, D., Fryer, B. J., 2011. The effect of $\mathrm{Ca}-\mathrm{Fe}-\mathrm{As}$ coatings on microbial leaching of metals in arsenic bearing mine waste. J. Geochem. Explor. 110, 23-30.

Zobrist. J., Dowdle, P.R., Davis, J.A, Oremland, R.S., 2000. Mobilization of arsenite by dissimilatory reduction of adsorbed arsenate. Environ. Sci. Technol. 34, 47474753. 